\title{
DOES UNEMPLOYMENT LEAD TO THE BREAKDOWN OF A MARRIAGE? EVIDENCE FROM THE SLOVAK REPUBLIC
}

\author{
JAKUB HARMAN ${ }^{\mathrm{i}}$
}

\begin{abstract}
In a sample of 79 districts of the Slovak Republic for the period 1997 - 2019, we examine the connection between the unemployment rate and the crude divorce rate. Our findings reveal a negative and statistically significant relationship, which suggests a procyclical nature in terms of the economic cycle. The estimated coefficients are relatively consistent even after the addition of control variables considering socio - economic factors or fixed effects. The results of the regression analysis show that an increase in the unemployment rate by one percentage point is accompanied by a decrease in the crude divorce rate by an average of 0.024 units. These findings support the assumptions of the theory of the high costs of divorce that spouses must bear. In a period of high unemployment, it is more acceptable for spouses to stay married than to bear the high costs associated with legal proceedings or the loss of part of the joint savings. The analysis of possible non-linear relationships between the unemployment rate and the crude divorce rate also showed a negative relationship. Quantile regression also points to the $U$-shaped relationship between variables and supports the opportunity theory. ${ }^{\text {ii }}$
\end{abstract}

Keywords: crude divorce rate, unemployment, motivation, opportunity.

JEL Classification: $E 24, K 42$

\section{INTRODUCTION}

The main institution that supports the creation of life is the family. The family is a place where the character of person is formed or a place where he

${ }^{\text {i } U n i v e r s i t y ~ o f ~ E c o n o m i c s ~ i n ~ B r a t i s l a v a, ~ F a c u l t y ~ o f ~ N a t i o n a l ~ E c o n o m y, ~ D e p a r t m e n t ~ o f ~ S o c i a l ~}$ Development and Labour, Dolnozemská cesta 1, Bratislava, 852 35, Slovak Republic, E-mail: jakub.harman@euba.sk

Errors and omissions remain on the author of this article.

ii The paper is a part of the research project VEGA no. 1/0037/20 "New challenges and solutions for employment growth in changing socio-economic conditions". 
acquires the basic values of society. Marriages and divorces are one of the most important demographic events shaping the family and influencing the change in the structure of family life in Slovakia. This paper deals with the factors that affect divorce rates in the Slovak Republic. The main determinant of divorce we examine is the unemployment rate. In this paper, we observe whether the crude divorce rate and the unemployment rate move in a cyclical or counter-cyclical trend. There are many scientific publications and studies that address this issue, identifying several possible perspectives (Amato and Beatie, 2011). One of the causes of divorce is the so-called stress effect. Stress has a major impact on the quality of marriage, and several studies (Conger and Elder, 1994; Johnson and Booth, 1990) have examined the impact of unemployment on divorce in this regard.

The effect of stress says that the unemployment rate is positively correlated with the divorce rate. Initially, however, optimistic expectations arise regarding the labour market situation for one of the spouses. However, if even after a long period of time one of the spouses is unable to find work, a situation with increased stress arises between spouses, e.g. a wife's frustration that her husband can't find a job makes her more likely to divorce. This hypothesis was confirmed by analyses by Jalovaara (2003) or Hansen (2005), who examined stress on the part of husbands and wives in Finland and Norway. Lewin (2005) and Bumpass (1991) also identified the effect of stress. Their studies confirmed that increased unemployment of husbands leads to higher divorce rates.

A very important work is the work of economists Becker, Landes and Michael (1977), who argue that the main benefit of marriage lies in the interdependence of spouses, which results from their differentiated roles. The husband is considered primarily the breadwinner of the family and the wife is responsible for the running of the household and the reproductive function. The authors point out that if the wife's income is higher than that of the husband, this results in a higher discomfort for the husband and an increase in his stress level. This can in turn lead to a higher probability of marriage breakdown. Cherlin (1979) argues that a husband's inability to provide the necessary resources for the family leads to increased stress even when the wife is employed. According to these authors, the effect should be greater if the variables are lagged, because the stress of reducing job opportunities takes time to affect the breakdown of the marriage.

The second perspective (Amato and Beattie, 2011) focuses on the costs associated with divorce and says that divorces are costly in terms of living standards and the accumulation of wealth. These costs include court costs, lawyers' costs, moving to a new home for at least one and often both spouses, the purchase 
of new furniture, the division of matrimonial property and the general loss of economies of scale associated with splitting a household into two. During periods of high unemployment, spouses are reluctant to bear these costs for a number of reasons. One of them may be the unemployment of one of the spouses or the need to enter the labour market and start working due to the increased costs, even though there are few vacancies in the economy at that time. Another reason is that employed spouses may be concerned about future unemployment, which means that spouses value their current job more and are therefore reluctant to take the risk of divorce. McManus and DiPrete (2001) pointed out that economic interdependence between spouses has increased in recent decades due to the growing participation of women in the labour market, rising women's real wages, declining men's earnings (especially men without higher education) and greater domestic work sharing and raising children in marriage. We also include the variable for women's participation in the labour market in our research (see the Results chapter). According to this perspective, the relationship between unemployment and divorce rates should be negative and thus, with higher unemployment, the number of divorces will decrease. In the case of this perspective, the effect should be greater if the variables are contemporaneous, because the costs of divorce take effect immediately.

The third perspective, the so-called hybrid, combines the first two perspectives. According to this perspective, the relationship between the divorce rate and the unemployment rate should be negative if we measure both variables in the same period, because the effect of high divorce costs is manifested. On the contrary, we observe a positive relationship if the unemployment rate is measured in the previous period, as it expects a psychological factor of stress to manifest itself, which leads to an increase in divorce.

A study by Jensen and Smith (1990) used panel data for Denmark for analysis. In their work they came to the conclusion that unemployment really is a relevant source of instability marriages. The authors estimated the positive impact of male unemployment on the divorce rate.

Of course, there are analyses that negate the aforementioned research papers and did not find a statistically significant relationship between the rate of divorce and unemployment (Ariizumi and al., 2015). From this we conclude that it is correct to state that empirically based analyses show different results.

In our study we use panel data at the district level and unemployment over the same period and the rate of divorce for measuring variations in the economic cycle. Although from a theoretical point of view, the relationship between 
unemployment and divorce is not entirely clear, our results suggest that the divorce rate and the unemployment rate are negatively correlated, even after including of variables controlling time and district fixed effects. Also in econometric models we include control variables for further characteristics of the individual districts, such as religious differences, changes in the structure of the population, the participation of women in the labour force, the legislative amendments introduced by the entry of the Slovak Republic to the European Union in 2004 and adopt the euro in 2009 as the new currency. Almost all the results show a strong pro-cyclical behaviour of crude divorce rate. A similar methodology was chosen by González - Val and Marcén (2015).

In his study, Schaller (2013) suggests that in the event of changes in the labour market, a situation may arise where married couples postpone important decisions. Therefore, it may happen that the effect of divorce will not manifest itself until the following years, when married couples make their decisions. As part of the solution to this problem, we also included delayed unemployment rates and delayed income levels in the analysis. Amato and Beattie (2011) apply the same approach, although it is not entirely clear, how long the delay can reveal this effect. Our results suggest that we can confirm this hypothesis, as the unemployment rate of one or two years has a statistically significant effect on divorce rates. The same applies to income.

In their contribution, González - Val and Marcén (2015) used a new approach to the analysis of the issue by examining the possible non-linear relationship between the crude divorce rate and the unemployment rate. The authors justify this by saying that the specific characteristics of the countries they studied, such as the unemployment rate, may not have the same distribution as the divorce rate. The authors use nonparametric methods and quantile regression, finding that the decrease in the divorce rate is greater if the unemployment rate is in the range of $15 \%$ to $25 \%$. However, the divorce rate is still pro-cyclical. In addition, the quantile regression analysis points to a non-linear relationship between divorce rates and changes in the unemployment rate with a greater negative impact on divorce rates in countries with higher divorce rates. We apply similar methods in our paper (see chapter Results).

Hellerstein and Morrill (2011) confirmed that there is a robust negative relationship between divorce rates and unemployment in the US, with an increase in the unemployment rate by one percentage point resulting in a reduction in the divorce rate by 0.043 units. Their result suggests a pro-cyclical character and is robust to a number of alternative empirical specifications of the estimated models. 
The authors Jimenéz-Rubio, Garoupa and Rosales (2016) chose an almost identical methodology as we did. On panel data from 50 provinces of Spain, they estimated the determinants of crude divorce rate. According to the results, the socalled Express Divorce Law (adopted in 2005) seems to be positively correlated with the divorce rate in the short term. Level of income and growth of income, female employment rate, and the proportion of economic migrants also positively associated with the rate of divorce.

The results of the analysis of authors Doiron and Mendolia (2012) show, that couples in which the husband experiences a job loss, are more likely to divorce. The authors also distinguish the way, in which the dismissed lost their jobs. Release in the event of redundancy has a small positive, but statistically insignificant impact on the divorce, while the release because of poor performance of the employee has a higher positive impact.

Eliason (2011) examined the impact of job loss for men and women on the risk of marriage termination in Sweden. In his study, he found that in the event of a husband losing his job, there was an average 13\% higher chance, that the marriage would end in divorce. The estimated coefficient is statistically significant. If the wife loses her job, there is a chance, that the divorce will take place at about the same level, but it lacks statistical significance.

The impact of rising real estate and housing prices on divorce rates in China is being studied by Li (2018). Empirical results show that the growing housing prices significantly improve rate of divorce. With every 1 percent increase in housing costs, the divorce rate increases by 0.10 thousandths. The impact is, however, heterogeneous for different areas of China. Rising housing costs are significantly increasing the divorce rate in the eastern and central regions. In the western regions of China, the statistical significance of the increase in real estate and housing costs has not been demonstrated.

Very interesting conclusions of the study brought Weiss and Willis (1997), who argue that unexpected changes in income have an impact on the likelihood of divorce. Their results show that grow of husband's earnings reduces the likelihood, that the marriage falls apart. In the case of increased earnings of wives, the situation is exactly the opposite, higher wages of women lead to a higher chance of separation of spouses.

Compared to the previous literature, Kendall (2011) observed a non-traditional determinant of divorce rate - internet connection. In his paper, he assumed that the increase in Internet access significantly reduced the cost of finding a new partner. This should logically lead to an increase in divorce rates, as the costs of dissatisfied spouses would be at least partially reduced. Thorough examination of the theory, 
however, suggests that even if the cost of finding a partner with the growth of the Internet dropped, it does not lead inevitably to increased probability of divorce.

The rest of this paper is divided into chapters, with Chapter 2 pointing to the data used. The third chapter describes the research methodology used. Chapter 4 shows the results obtained by our analysis and the last chapter 5 concludes.

\section{DATA}

All used data are recorded at the level of 79 districts of the Slovak Republic. Except for some variables, they all cover periods 1997 - 2019. The dependent variable in all econometric models is the crude divorce rate. It is calculated as the ratio of divorces per 1000 inhabitants during a reference period ${ }^{\text {iii }}$. It is the crude divorce rate, that is a frequently used indicator used by scientific researchers in their analyses (Amado and Beattie, 2011; Friedberg, 1998). As reported by González-Val and Marcén (2015), the rate might be affected by the structure and marital status of the population. The divorce rate may be low either because the marriage rate is low or because the marriage is less likely to end in divorce. Despite these shortcomings, we consider the crude divorce rate to be the best indicator for monitoring the causes of marital breakdowns. We assume, that due to the fact, that we use a longer time series of the indicator, these effects will be negligible. Data on the gross divorce rate were collected from the databases of the Statistical Office of the Slovak Republic.

An excellent indicator, that can measure the fluctuation of the economic cycle is the unemployment rate. It is this indicator, that we use in our research. The unemployment rate represents the share of the labour force, that is out of work and looking for employment in the total number of economically active population. The economically active population includes both employed and unemployed workers in the labour market. The unemployment rate is commonly and widely used variable in the general research of the impact of the economic cycle because it can capture not only the situation in the labour market, but to some extent economic uncertainty. Despite the widespread use of this indicator in the literature, we assume, that it may have some weaknesses, for example that it does not capture the impact of the recession or expansion of the business cycle fully in the year under review. However, we confront this problem by estimating the impact of

\footnotetext{
iii The exact calculation: Crude divorce rate $=$ (number of divorces in a given territorial unit $/$ average population of the territorial unit) ${ }^{*} 1000$
} 
unemployment up to the previous three years using lagged variables. Data on the unemployment rate were collected from the databases of the Statistical Office of the Slovak Republic.

The average values of the gross divorce rate and the unemployment rate of 79 districts of the Slovak Republic in the period 1997 - 2019 are shown in Table $1^{\text {iv }}$. The data are sorted by unemployment, from lowest to highest. At first glance, we can observe a large variance and a slightly negative relationship between the variables. Districts with a low unemployment rate more often have higher divorce rates and vice versa. Graphical representation of the unemployment rate and the crude divorce rate in individual districts provides Figure 1. However, the rule cannot be applied generally to all observed districts. Since the same legislative and legal conditions for obtaining a divorce apply throughout Slovakia, we must look for answers in other factors. For districts, that are considered strongly religious ${ }^{\mathrm{v}}$ (Šprocha and Majo, 2016) we observe a significantly lower divorce rate compared to other districts. This statement is also confirmed by the display of data on Cartogram 1 and 2, where we observe an inverse relationship between unemployment and divorce rates in religiously oriented districts. The negative correlation is also confirmed by Figure 3, which shows data for all districts of the Slovak Republic for all observed periods. Fitted line points to a weak, but slightly negative relationship between variables. When looking at the quadratic shape of the curve with fitted values, we observe the shape to the letter U. This suggests that at lower unemployment rates, the divorce rate is at higher values and gradually decreases. From this we could conclude that there is a second perspective, which deals with the high costs of divorce. From a value of approximately $22.7 \%$ of the unemployment rate, we observe a growing trend associated with a growing number of divorces.

Figure 2 shows the movement of the divorce rate and the unemployment rate at the aggregate level for the whole of the Slovak Republic. Showing of variables at the national level provides a simple view of their relationship and helps to identify the period of recession. We can see from the figure, that the divorce rate corresponds to the effects of unemployment in the pro-cyclical direction. However, we cannot draw conclusions from such an analysis. Therefore, we address this issue in more detail.

\footnotetext{
iv All figures and tables can be found in the Annex.

v Those are: Banska Stiavnica, Bardejov, Cadca, Detva, Dolny Kubin, Gelnica, Kezmarok, Kysucke Nove Mesto, Levoca, Namestovo, Poprad, Presov, Sabinov, Spisská Nova Ves, Stara Lubovna, Svidnik, Tvrdosin, Zvolen, Zarnovica, Ziar nad Hronom
} 
Other control variables are also included in the estimated models to determine the robustness of the estimated coefficients at the unemployment rate. The male unemployment rate is one of the control variables, because we assume, that men are less likely to change jobs if there is a change in an individual's marital status. Data is collected from the database of the Statistical Office Slovak Republic and due to the lower availability cover the period of $2001-2019$.

In order to be able to take into account the income of individuals and its impact on divorce rates, a variable explaining the average monthly wage in the relevant year is incorporated into the models. A better variable, that could explain the possible risk of divorce for financial and property reasons, would be gross domestic product per capita. Due to the lack of data at the district level, we chose the average monthly wage as a proxy variable expressing the level of wealth in the respective districts. The data were collected from databases of the Ministry of Labour, Social Affairs and Family of the Slovak Republic and cover the period 2008 - 2019. The amounts of monthly income as well as the distribution of wages at the national level are shown in Cartogram 3. Looking at Cartograms 1 and 3 we observe, that in districts with higher income there is also a higher divorce rate. This suggests a positive relationship between the variables. Of course, drawing such conclusions is ambiguous. We examine the relationship in detail in the Results chapter.

The consideration of the age structure of the population of individual districts is controlled by a variable showing the median age. We assume, that older people will have a lower motivation to divorce and also a lower motivation to change or leave their job. Therefore, we expect the divorce and unemployment rates to be lower with higher age. Data on the median age are obtained from the Statistical Office of the Slovak Republic and follow the entire time period $1997-2019$.

The dummy variables that control changes in political and legislative norms like accession to the European Union in 2004 and the adoption of the euro as national currency in 2009. These variables become "1" if the country already belongs to the European Union or has adopted the euro. If this has not yet happened, the variables have a value of " 0 ".

\section{Methodology}

The general equation to estimate has the following form:

$$
C D R_{i t}=\beta_{0}+\beta_{1} \text { Unemployment }_{i t}+\beta_{2} X_{2}+\alpha_{t}+\psi_{i}+\psi_{i} \alpha_{t}+\varepsilon_{i t}
$$

where $\mathrm{CDR}$ is the crude divorce rate of the district $i$ in year $t$, Unemployment it is the unemployment rate of the district $\mathrm{i}$ in year t. $X_{2}$ shows the 
control variables, that are included in the model for checking the robustness of unemployment rate estimates. $\alpha_{t}$ is a vector of time effects individual districts $\left(\sum_{t=1}^{t-1}\right.$ Year $\left._{t}\right)$, which captures the effect of unobserved characteristics, that differ at the level of districts and also in time. $\psi_{i}$ is the vector of fixed effects, individual district $\sum_{i=1}^{n-1}$ District $_{i}$, which captures the effect of unobserved characteristics that differ at the level of districts and are time-invariant. $\psi_{i} \alpha_{t}$ expresses a linear time trend specific to each monitored district $\left(\sum_{i=1}^{n-1}\right.$ District $_{i} *$ Year $\left._{t}\right) . \varepsilon_{i t}$ is the residual or error of the model.

This specification of the econometric model is used by several authors (Schaller, 2013; González - Val and Marcén, 2015; González - Val and Marcén, 2017). It is based on the exogenity of differences in unemployment rates between districts, although some concerns may still arise. According to González - Val and Marcén (2015), it is likely, that if women's marital status changes, their approach to finding a job may change significantly, which in turn affects the unemployment rate. We will confront this problem in the next chapter.

The main interest of this paper is to find out the nature and size of the coefficient, which speaks to the effect of the unemployment rate on the divorce rate. From a theoretical point of view, we could not confirm, whether this coefficient will be positive and will be anti-cyclical in nature, or negative and thus pro-cyclical.

\section{RESUltS}

Table 2 shows the results of the correlation analysis of paired coefficients between individual variables. We observe a correlation coefficient between divorce rate and unemployment rate with a value of -0.297 ( $\mathrm{p}$-value $=0.000$ ), which suggests, that there is a negative and significant relationship between the variables. From this we could conclude the pro-cyclical nature of this relationship. This result is also supported by Figure 3. The correlation coefficient acquires a very similar value, even if we observe the relationship between the male unemployment rate and the divorce rate, where it acquires a value of -0.236 ( $p$-value $=0.000)$. There is almost no correlation between income and divorce $(0.084 ; \mathrm{p}$-value $=0.010)$ and therefore these variables have no link between them. This statement seems unlikely to us, which we try to prove in the following pages using regression analysis. An interesting value is the correlation coefficient in the relationship between divorce rate and women participation in the labour market, which speaks of a strong link between variables $(0.564 ; \mathrm{p}$-value $=0.000)$. In translation, this means that higher participation of women in the labour market leads to an increase in divorce rates. 
We expect similar results in the case of regression analysis. The relationship between divorce and religion is expected to be negative. Divorces contradict the Christian faith, which is also reflected in the value of the coefficient -0.405 (pvalue $=0.000$ ). Legislative, legal and political changes according to the correlation analysis do not have a significant effect on the divorce rate. In the case of accession to the European Union, the value of the coefficient is even 0.000 (p-value $=0.993$ ), which indicates zero correlation. In the case of the adoption of the euro as the new legal tender in 2009, it is 0.184 ( $\mathrm{p}$-value $=0.000$ ), which indicates a weak but slightly positive correlation between the variables.

Table 3 shows the results of the regression analysis of the models from equation (1), all regressions being weighted by the population of the given district. The model in column (1) shows the estimated coefficient without any control variables or fixed district and year effects or their interaction, which acquires a negative and statistically significant value of -0.024 . After adding the fixed effects of districts, time effects and the interaction between them, column (2), the estimated coefficient remained consistent, statistically significant and changed only minimally to -0.026 . That implies, that the partial removal of unobserved characteristics results in a slight increase in the impact of unemployment on divorce. The result shows, that an increase in the unemployment rate by one percentage point leads to a reduction in the number of divorces per 1,000 inhabitants by an average of 0.026 . In the case of average crude divorce rate in the Slovak Republic it would lead to a reduction of approximately $1.32 \%$. This statement is also confirmed by the estimated coefficient in column (3), where the variable crude divorce rate is in the logarithmic form. The results are consistent with those of other studies (Schaller, 2013; González - Val and Marcén, 2015).

There may be concerns among the variables as to whether exogeneity is guaranteed. There is a presumption, that the increased / decreased unemployment rate is caused by the divorce. Fernandez and Wong (2014) state that if women do not marry during their lifetime, or divorced women do not remarry, it is likely that more women will participate in the labour market. However, empirical confirmation of this relationship is lacking in the literature. González - Val and Marcén (2015) point out, that the increase in the divorce rate causes only a negligible change in the employment rate of women. Regarding male unemployment, we assume that men are more resilient and less prone to job loss in the labour market if they lose their married status. For this reason, we estimate 
equation (1) again, but we use the male unemployment rate ${ }^{\mathrm{vi}}$ as a dependent variable. Column (4) shows the estimated coefficient without the involvement of control variables and also without the control of fixed or year effects. The value of the estimated coefficient is very similar to that in column (1) and again remains negative and statistically significant. Consistent estimates are also provided by the models in columns (5) and (6), which include control variables for fixed and year effects, as well as their interaction and subsequently a logarithmic dependent variable in column (6). By including the variable for the male unemployment rate, we were able to make sure that the relationship between the overall unemployment rate and the crude divorce rate does exist and is slightly negative.

In addition to unemployment, which is undoubtedly an important determinant of divorce, it is highly probable, that the economic cycle also has a significant effect on the probability of divorce and thus also on the divorce rate. If the spouses are able to be sufficiently financially secure even after their divorce, so their standard of living will not fall, or will remain unchanged, we assume, that there will be a positive correlation between income and divorce. In the opposite situation, where divorce is likely to lower significantly the standard of living of individuals during an economic recession, we expect a negative relationship between income and divorce. Such people have a significantly lower motivation to undergo the divorce process and thus lose part of their income, which they shared as spouses. Becker and al. (1977) see another reason for the negative relationship between divorce rate and income in possibility of owning assets that are undervalued during a recession and, in addition, their sale can be lengthy and costly. Such assets include, for example, real estate, expensive cars, securities or art collections. In order to be able to control the impact of the economic cycle in the regression analysis, we use the amount of the average monthly income in a given district in a given year as a proxy variable evaluating household income. The estimated coefficients are found in Table 3 in columns (7) - (10). Without any control variables, we estimate the model in column (7). The income coefficient is positive but not statistically significant, which suggests that income does not affect the divorce rate in Slovakia. However, in another model (8), which controls year and district fixed effects, the statistical significance of income was demonstrated, and, in addition, the coefficient increased significantly to 1.165 . From this it follows, that the increase in income in the household leads to an increased divorce

\footnotetext{
${ }^{\text {vi }}$ The male unemployment rate is calculated as the share of unemployed men looking for work in the total economically active population in a given year.
} 
rate, as increased income leads to the fact, that couples have more money to set up a new life after divorce or being able to easily cope with the loss of value of common assets. This is also confirmed by the estimated coefficient in the following model, column (9), which also includes the variable for the unemployment rate. The value of the coefficient of effect of income remained statistically significant and decreased slightly but remains positive. The unemployment rate is consistent even when including a variable that considers the economic cycle. The model in column (10) shows the estimate of income if the divorce rate is in logarithmic form and supports the previous results. If the amount of household income increased by $1 \%$, the crude divorce rate would increase by $0.62 \%$. Applying this value to the average divorce rate in Slovakia, we find that there would be approximately 0.12 more divorces per 1,000 inhabitants.

Important factors, that may affect whether a spouse separates forever or remains married, may not come from the economic environment alone. González - Val and Marcén (2015) state, that political and institutional changes in a country can also affect divorce rates. A significant event, that took place on the political scene during the period we monitored was the accession of the Slovak Republic to the political and economic union, the European Union. The second event was the adoption of the new legal tender in 2009 - the euro. In modelling these phenomena, we used the method of dummy variables. If the Slovak Republic belonged to the European Union in the observed year, the variable acquires the value "1". In the opposite scenario, it is the other way around and the value of the variable is " 0 ". We use a similar principle in the case of the adoption of the euro. Since 2009, the variable has a value of "1" and in the previous period a value of " 0 ". The results of the regression analysis are summarized in Table 4. The presence of the Slovak Republic in the European Union is statistically significant according to the model in column (1) and has a positive effect on the divorce rate. From this we can conclude that the opening of new markets on European soil, which opened the space for greater employment of women or men in the labour market, leads to the fact that Slovak marriages are falling apart to a greater extent. One of the factors may also be the easier inflow of foreign capital into the economy of the Slovak Republic, as the barriers that previously prevented expansion into the Slovak market have been removed. The coefficient for the unemployment rate remained statistically significant. Its value has not changed and continues to be pro-cyclical. Minimal differences are noticeable, when we replaced the overall unemployment rate with the male unemployment rate (2). The coefficient of the dummy variable remained statistically significant, 
but its value decreased slightly. Taking into account the change in legal tender from the Slovak koruna to the euro in 2009, column (3), we observe, that the coefficient is not statistically significant, and the impact of the unemployment rate remains consistent. When the unemployment rate was replaced by the male unemployment rate, the coefficient of change of legal tender changed to a statistically significant one and its value increased significantly to the level of 0.361. This means, that even such a change has a significant impact on the stability of marriages in Slovakia. The impact of the male unemployment rate did not change and remained almost at its original level. Columns (5) and (6) include both dummy variables in the models, and we state that the coefficients at the unemployment rate are unchanged and remain statistically significant. The acquired values for dummy variables are also statistically significant and show a consistent character compared to previous models.

A very important factor influencing whether spouses divorce or remain in the sacred union is their age. According to Peters (1986), older people are less prone to divorce than younger people, because they are used to each other and are less determined to make such a fundamental change in their lives. For this reason, we expect, that the age structure of the population will mean a lower divorce rate with older age. In order to be able to control the age structure of Slovakia, we use the median age indicator for each district as a proxy variable. This indicator divides the population into $50 \%$ of those who are younger than the value of the indicator and $50 \%$ of those who are older. The results are shown in Table 5. Column (1) includes this variable and its coefficient is statistically significant and positive. This suggests, that the higher the age of the Slovak population, the higher the divorce rate. As the population of the Slovak Republic ages, the number of divorces is also increasing. Interestingly, the impact of the unemployment rate remained negative but lost statistical significance. Women's participation in the labour market is also included as a control variable and is shown by the model in column (2). The coefficient is assumed to be positive and statistically significant. This suggests, that if there are more women in the labour market, the divorce rate also increases. We associate this phenomenon mainly with the fact that women, who find work, have an increased income, and therefore it is easier for them to become independent in the event of divorce. The unemployment rate coefficient remains pro-cyclical and statistically significant at the $90 \%$ significance level. The inclusion of both mentioned variables in model (3) does not change their statistical significance or their size. It is interesting, however, that for the first time, the sign of the unemployment rate has acquired a positive character, which, however, is very close 
to zero and is not statistically significant. Religion is an important cultural element, that significantly affects divorce rates. In the Slovak Republic, the most common religion is Catholic. However, there are districts, where people are considered stronger believers who follow Catholic teaching more honestly (Šprocha and Majo, 2016). In order to control the influence of religion, we use a dummy variable, the value of which "1" is acquired by districts that are considered strongly religious. Other districts where devotion to the faith is more moderate acquire a value of "0". The results are again observable in Table 5. As expected, the coefficient for religion, column (4), is negative (-0.554) and statistically significant. This means that strong Catholicism leads to a lower divorce rate by an average of up to 0.5 divorces per 1,000 inhabitants. The unemployment rate maintains pro-cyclical value and statistical significance. The inclusion of all three variables (column (5)) confirms the effects of all variables identified so far. The unemployment rate is losing statistical significance and becoming positive. The models in columns (6) and (7) assert the findings from previous models even if the unemployment rate has been replaced by the male unemployment rate. However, it is not statistically significant and its values are equal and very close to zero.

Whether partners choose to end their marriage may be due to the accumulation of stress over a longer period of time. Loss of employment in the past can lead to accumulation of tension between spouses who either for financial or family reasons decided to continue living together despite the loss of job. Due to time and the growing number of disagreements and conflicts, the spouses decide to end their marriage even though their financial situation is not ideal and the costs of divorce are high. Amato and Beattie (2011) expect that in such a situation, the unemployment rate at time $t$ will have a negative effect on the divorce rate and the delayed unemployment rate will have a positive effect. To point out the validity of this statement in the Slovak Republic, we included in the model the lagged variables for the unemployment rate up to the year $t$ - 2 , as it is possible that there is a difference between the date of marriage and the date of divorce.

The results of the regression analysis are shown in Table 6. In column (1), we observe a negative relationship with the unemployment rate in year $t$, which, however, is not statistically significant and is very close to zero. However, the unemployment rate in the previous year $(t-1)$ is statistically significant and is also negative. The cumulative effect of the unemployment rate is -0.032 with the common test F-statistic $=14.07(\mathrm{p}>\mathrm{F}=0.000)$. This means that the impact of the unemployment rate is consistent even after taking into account the time lag. As in previous models, we used the male unemployment rate in this case as a variable controlling potential bias 
(column (2)). The effect of the unemployment rate again showed statistical significance only with a delayed unemployment rate with a cumulative effect of 0.030 and with a common test F-statistic $=34.57(\mathrm{p}>\mathrm{F}=0.000)$.

If we take into account the high costs of divorce, then we must also take into account household income. To account for fluctuations in income due to the economic cycle, we used the same method as for the unemployment rate, and we included in the models lagged variables for the amount of income, which we use as a proxy variable taking into account the economic cycle. Column (3) provides a view of the estimated coefficients. All the estimated coefficients are statistically significant and positive, indicating that higher incomes lead to an increase in the divorce rate. The total effect of income has a cumulative value of up to 1.095 with test F-statistics $=18.61(\mathrm{p}>\mathrm{F}=0.000)$. The effect will be halved if we add the unemployment rate, including lags (column (4)). Almost all the estimated coefficients in this model lost statistical significance, but their nature in the form of a negative effect of the unemployment rate and a positive effect of income remained. That implies that the psychological approach in relationship of divorce rate and the unemployment rate cannot be confirmed.

So far, we have assumed that the relationship between the crude divorce rate and the unemployment rate is linear. The next part of the analysis deals with the nonlinear possibilities of this relationship. A similar approach is used by studies by González - Val and Marcén (2015), who examine the relationship in a sample of 29 European countries. We assume that the districts where it is difficult to find a job, districts with higher unemployment rates, will show a lower rate of divorce because it is harder to keep living standards after job loss. The benefits of the spouses remaining married are higher in districts with a higher unemployment rate. In order to be able to test these effects and accept or reject them, we perform a kernel density analysis that gives us the answer to the distribution of data across the sample and a quantile regression that gives the answer to a possible nonlinear relationship between variables. The advantage of nonparametric tools is that they do not assume an exact functional relationship between the variables and therefore can take into account nonlinearity that changes over time. Figure 4 shows kernel density analysis of the relationship between the crude divorce rate and the unemployment rate. In the absence of a relationship between the variables, the data density would be concentrated on one of the axes. From the figure we observe that the relationship between the variables is not strong but still a certain one exists. The highest concentration of data is around 1.8 divorces per 1000 inhabitants and at the same time a $3 \%$ unemployment rate. There is a slightly negative relationship 
between the variables, and thus if the divorce rate decreases, then unemployment increases, which follows and confirms the results obtained using linear methods. A similar display of data is provided by Figure 5, which shows the issue in 3D.

To further elucidate the relationship between the variables, we performed an analysis using a nonparametric method ${ }^{\text {vii }}$. Figure 6 provides an overview of the estimated model with a 95\% confidence interval. The expected negative relationship with the unemployment rate until around $22.5 \%$ was confirmed. At higher unemployment rates, the crude divorce rate increased significantly, indicating that the high rate of unemployment, which have economic and social problems in families and marriages leading to tension between spouses, resulting in increased divorce rate.

In order to be able to take into account possible heterogeneous effects in the relationship between divorce rate and unemployment rate, we estimate a quantile regression $^{\text {viii }}$. Quantile regression can take better account of data variability and possible fluctuations from the mean than the least squares method. The analysis also considers potential heteroscedasticity. Figure 7 provides an insight into the estimated model of quantile regression, which includes fixed effects as well as year effects and is weighted by the population of individual districts. The results are very similar to the previous ones. They support the assumption of a negative relationship between the variables in the first four quantiles, which suggests that in districts with a low divorce rate, the impact of the unemployment rate is higher than in other districts. From the 4th quantile, the relationship reverses and the curve becomes increasing. The values of the whole curve are very close to zero, which indicates that the relationship between the variables is weak.

\section{Conclusion}

The breakdown of a marriage is a very important moment in an individual's life. The paper deals with the relationship between the crude divorce rate and the unemployment rate. As for the theoretical aspects of the issue, the direction of the impact of loss of employment on the stability of marriage is not entirely clear. The potential impact of the unemployment rate can be understood from several perspectives. The effect of stress presupposes a positive effect of job loss on the probability of divorce, as the tension between the spouses increases. The opposite

\footnotetext{
${ }^{\text {vii }}$ We used the STATA program and the lpolyci command.

viii The estimated model has the form: $\mathrm{CDR}_{\mathrm{it}}=\beta_{0}(\mathrm{k})+\beta_{1}(\mathrm{k})$ Unemployment $\mathrm{it}_{\mathrm{t}}+\alpha(\mathrm{k})$ it $+\psi(\mathrm{k})_{\mathrm{it}}+\mathrm{e}_{\mathrm{it}}$, it, where $\mathrm{k}$ is the quantile corresponding to the crude divorce rate.
} 
effect is assumed by a perspective that considers the costs of divorce associated with, for example, legal acts, the division of property as a result of the breakdown of a marriage or the need to build a new background. Empirical research on a given relationship shows different results.

The paper examines data collected for all 79 districts of the Slovak Republic in the period 1997-2019. The results suggest that the relationship between crude divorce rate and unemployment rate is negative and statistically significant, suggesting a pro-cyclical nature of the response to changes in conditions with respect to the economic cycle. Several studies, the results of which are compared with ours, came to the same conclusions. Verification of the robustness and consistency of the estimates was performed by including control variables in the estimated models. Even after considering income levels, legislative changes, religion, women's participation in the labour market or the aging factor, the estimates were relatively stable. Minor fluctuations were observed in models that controlled population aging. However, the estimated coefficients were not statistically significant and were very close to zero. The inclusion of year fixed effects and district fixed effects also confirmed the consistency of the estimates.

The research results show that the effect of job loss is not very high. An increase in the unemployment rate by one percentage point leads to a decrease in the crude divorce rate by only 0.024 units ( 0.024 divorces per 1000 inhabitants). The results are almost identical even if the unemployment rate is replaced by the male unemployment rate, which we assume is more resilient to dismissal or change of employment due to a change in social status.

Nonparametric methods pointed to a U-shaped relationship. The effect of the unemployment rate first increases (in negative numbers) to about $30 \%$ and then approaches zero rapidly. Quantile regression also supports this finding. 


\section{REFERENCES}

1. Amato, P. R., and B. Beattie, (2011). Does the unemployment rate affect the divorce

2. rate? An analysis of state data 1960-2005. Social Science Research, 40: 705-715

3. Ariizumi, H., Y. Hu, and T. Schirle, (2015). Stand together or alone? Family structure and the business cycle in Canada. Review of Economics of the Household, 13: 135161.

4. Becker, G. S., E. M. Landes, and R. T. Michael, (1977). An economic analysis of marital instability. Journal of Political Economy, 85(6):1141-1187.

5. Bumpass, L.L., Martin, T.C., Sweet, J.A., 1991. The impact of family background and early marital factors on marital disruption. Journal of Family Issues 12, 22-42.

6. Cherlin, A. (1979) Work Life in Marital Dissolution. In: Levinger, G. and Moles, O.C., Eds., Divorce and Separation, Basic Books. New York, 151-166.

7. Conger, R.D., Elder, G.H., (1994). Families in Troubled Times: Adapting to Change in Rural America. Aldine de Gruyter, New York.

8. Doiron, D., Mendolia, S., (2012). The Impact of Job Loss on Family Dissolution. Journal of Population Economics. 25. 367-398. 10.1007/s00148-010-0353-5.

9. Eliason M (2011) Income after job loss - the role of the family and the welfare state. Appl Econ 43(5):603-618

10. Fernández, R., and J. C. Wong, (2014a). Divorce Risk, Wages and Working Wives: A Quantitative Life-Cycle Analysis of Female Labour Force Participation. The Economic Journal, 124(576): 319-358.

11. Friedberg, L., (1998). Did Unilateral Divorce Raise Divorce Rates? Evidence

12. from Panel Data. American Economic Review, 88(3): 608-627.

13. González-Val, R., Marcén, M., (2015). Divorce and the business cycle: a crosscountry analysis," Review of Economics of the Household, Springer, vol. 15(3), 879904

14. González-Val, R., Marcén, M., (2017). Unemployment, marriage and divorce. Applied Economics. 50. 1-14. 10.1080/00036846.2017.1366642.

15. Hellerstein, J. K., and M. S. Morrill, (2011). Booms, Busts, and Divorce. The B.E. Journal of Economic Analysis \& Policy, 11(1)

16. Ioannides, Y. M., and H. G. Overman, (2004). Spatial evolution of the US urban system. Journal of Economic Geography, 4(2): 131-156.

17. Jensen, P., and N. Smith, (1990). Unemployment and marital dissolution. Journal

18. of Population Economics, 3(3): 215-229.

19. Jiménez-Rubio, D., Garoupa, N., Rosales, V., (2016). "Explaining divorce rate determinants: new evidence from Spain," Applied Economics Letters, Taylor \& Francis Journals, vol. 23(7), 461-464

20. Johnson, D., Booth, A., (1990). Rural economic decline and marital quality: a panel study of farm families. Family Relations 39, 159-165. 
21. Kendall, T., (2011). The Relationship Between Internet Access and Divorce Rate. Journal of Family and Economic Issues. 32. 449-460. 10.1007/s10834-010-9222-3.

22. Lewin, A.C., (2005). The effect of economic stability on family stability among welfare recipients. Evaluation Review 29, 223-240.

23. McManus, P.A., DiPrete, T.A., 2001. Losers and winners: the financial consequences of separation and divorce for men. American Sociological Review 66, 246-268.

24. Peters, E. H., (1986). Marriage and Divorce: Informational Constraints and Private Contracting. American Economic Review, 76(3), 437-454.

25. Schaller, J., (2013). For richer, if not for poorer? Marriage and divorce over the business cycle, Journal of Population Economics, 26: 1007-1033.

26. South, S. J., (1985). Economic conditions and the divorce rate: A time-series analysis of the postwar United States. Journal of Marriage and the Family, 47: 31-41

27. Šprocha, B., Majo, J., (2016). Storočie populačného vývoja Slovenska II.: populačné štruktúry. Infostat. ISBN 978-80-89398-31-7

28. Weiss Y, Willis R (1997). Match quality, new information, and marital dissolution. J Labor Econ 15(1): S293-S329 


\section{APPENDIX}

Table 1 Average gross divorce rate and unemployment rate by district

\begin{tabular}{|c|c|c|}
\hline District & Crude divorce rate & Unemployment rate \\
\hline Bratislava IV & 2,82 & 3,51 \\
\hline Bratislava I & 2,10 & 3,74 \\
\hline Bratislava III & 2,47 & 3,81 \\
\hline Bratislava V & 2,73 & 3,84 \\
\hline Bratislava II & 2,61 & 3,94 \\
\hline Senec & 2,33 & 5,04 \\
\hline Pezinok & 2,44 & 5,30 \\
\hline Trencin & 1,91 & 5,36 \\
\hline Ilava & 1,97 & 5,89 \\
\hline Piestany & 1,96 & 6,70 \\
\hline Trnava & 2,13 & 6,95 \\
\hline Puchov & 1,71 & 7,16 \\
\hline Malacky & 2,18 & 7,20 \\
\hline Banska Bystrica & 2,46 & 7,65 \\
\hline Nove Mesto nad Vahom & 2,07 & 7,87 \\
\hline Zilina & 1,88 & 8,13 \\
\hline Hlohovec & 2,02 & 8,34 \\
\hline Galanta & 2,15 & 8,36 \\
\hline Myjava & 2,03 & 8,47 \\
\hline Skalica & 2,13 & 8,55 \\
\hline Nitra & 2,09 & 9,30 \\
\hline Kosice IV & 2,21 & 9,33 \\
\hline Martin & 2,40 & 9,38 \\
\hline Zvolen & 2,43 & 9,80 \\
\hline Kosice I & 2,51 & 9,89 \\
\hline Dunajska Streda & 2,27 & 10,05 \\
\hline Považska Bystrica & 1,83 & 10,11 \\
\hline Prievidza & 2,24 & 10,12 \\
\hline Banovce nad Bebravou & 1,99 & 10,23 \\
\hline Kosice II & 2,38 & 10,23 \\
\hline Senica & 2,15 & 10,30 \\
\hline Liptovsky Mikulas & 2,09 & 10,39 \\
\hline Kosice III & 2,36 & 10,63 \\
\hline Topolcany & 2,04 & 10,95 \\
\hline Cadca & 1,46 & 11,17 \\
\hline Ruzomberok & 1,93 & 11,33 \\
\hline Partizanske & 2,01 & 11,58 \\
\hline Turcianske Teplice & 1,94 & 11,83 \\
\hline Tvrdosin & 1,03 & 11,95 \\
\hline Sala & 2,20 & 11,99 \\
\hline
\end{tabular}




\begin{tabular}{|c|c|c|}
\hline District & Crude divorce rate & Unemployment rate \\
\hline Namestovo & 0,74 & 12,11 \\
\hline Poprad & 1,71 & 12,11 \\
\hline Bytca & 1,39 & 12,17 \\
\hline Stara Lubovna & 0,82 & 12,62 \\
\hline Kysucke Nove Mesto & 1,67 & 12,83 \\
\hline Zlate Moravce & 1,75 & 12,91 \\
\hline Dolny Kubin & 1,59 & 13,35 \\
\hline Nove Zamky & 2,22 & 13,57 \\
\hline Ziar nad Hronom & 2,20 & 13,77 \\
\hline Komarno & 2,29 & 14,99 \\
\hline Presov & 1,48 & 15,08 \\
\hline Detva & 1,82 & 15,59 \\
\hline Levice & 2,20 & 15,59 \\
\hline Humenne & 1,73 & 15,63 \\
\hline Brezno & 1,82 & 15,65 \\
\hline Banska Stiavnica & 2,30 & 15,96 \\
\hline Spisska Nova Ves & 1,53 & 16,79 \\
\hline Krupina & 1,75 & 17,00 \\
\hline Stropkov & 1,26 & 17,35 \\
\hline Levoca & 1,25 & 17,39 \\
\hline Snina & 1,50 & 17,63 \\
\hline Zarnovica & 1,87 & 18,38 \\
\hline Svidnik & 1,29 & 18,60 \\
\hline Bardejov & 1,19 & 18,83 \\
\hline Medzilaborce & 1,35 & 18,98 \\
\hline Michalovce & 1,90 & 19,12 \\
\hline Gelnica & 1,31 & 19,93 \\
\hline Kosice - okolie & 1,49 & 20,03 \\
\hline Lucenec & 2,43 & 20,58 \\
\hline Vranov nad Toplou & 1,26 & 20,87 \\
\hline Poltar & 1,94 & 21,22 \\
\hline Sabinov & 0,85 & 21,53 \\
\hline Sobrance & 1,29 & 21,85 \\
\hline Trebisov & 1,68 & 22,96 \\
\hline Vel'ky Krtis & 1,89 & 23,11 \\
\hline Kezmarok & 1,23 & 23,89 \\
\hline Roznava & 2,25 & 24,44 \\
\hline Revuca & 2,13 & 26,68 \\
\hline Rimavska Sobota & 2,17 & 29,09 \\
\hline Slovak Republic & 1,97 & 12,44 \\
\hline
\end{tabular}

Source: Statistical Office of the Slovak Republic

Note: The data show the average value of the gross divorce rate and the unemployment rate by district for the period 1997 - 2019. 
Table 2 Correlation matrix

\begin{tabular}{|c|c|c|c|c|c|c|c|c|c|}
\hline & Crude divorce rate & Unem. rate & $\begin{array}{l}\text { Unem. rate } \\
\text { (male) }\end{array}$ & Income & $\begin{array}{c}\text { Age } \\
\text { (median) }\end{array}$ & Women & Religious & Euro & EU \\
\hline Crude divorce rate & 1.000 & & & & & & & & \\
\hline Unemployment & -0.297 & 1.000 & & & & & & & \\
\hline Unemployment(male) & $\begin{array}{r}(0.000) \\
-0.236 \\
(0.000)\end{array}$ & $\begin{array}{r}0.989 \\
(0.000)\end{array}$ & 1.000 & & & & & & \\
\hline Income & $\begin{array}{r}0.084 \\
(0.010)\end{array}$ & $\begin{array}{r}-0.654 \\
(0.000)\end{array}$ & $\begin{array}{l}-0.645 \\
(0.000)\end{array}$ & 1.000 & & & & & \\
\hline Median age & $\begin{array}{r}0.405 \\
(0.000)\end{array}$ & $\begin{array}{r}-0.544 \\
(0.000)\end{array}$ & $\begin{array}{l}-0.523 \\
(0.000)\end{array}$ & $\begin{array}{r}0.532 \\
(0.000)\end{array}$ & 1.000 & & & & \\
\hline Women & $\begin{array}{r}0.564 \\
(0.000)\end{array}$ & $\begin{array}{r}-0.331 \\
(0.000)\end{array}$ & $\begin{array}{r}-0.252 \\
(0.000)\end{array}$ & $\begin{array}{r}-0.269 \\
(0.000)\end{array}$ & $\begin{array}{r}0.185 \\
(0.000)\end{array}$ & 1.000 & & & \\
\hline Religious & $\begin{array}{l}-0.405 \\
(0.000)\end{array}$ & $\begin{array}{r}0.193 \\
(0.000)\end{array}$ & $\begin{array}{r}0.165 \\
(0.000)\end{array}$ & $\begin{array}{r}-0.166 \\
(0.000)\end{array}$ & $\begin{array}{r}-0.392 \\
(0.000)\end{array}$ & $\begin{array}{r}-0.198 \\
(0.000)\end{array}$ & 1.000 & & \\
\hline Euro & $\begin{array}{r}0.000 \\
(0.993)\end{array}$ & $\begin{array}{r}-0.240 \\
(0.000)\end{array}$ & $\begin{array}{r}-0.187 \\
(0.000)\end{array}$ & $\begin{array}{r}0.237 \\
(0.000)\end{array}$ & $\begin{array}{r}0.582 \\
(0.000)\end{array}$ & $\begin{array}{r}0.106 \\
(0.000)\end{array}$ & $\begin{array}{r}0.000 \\
(1.000)\end{array}$ & 1.000 & \\
\hline EU & $\begin{array}{r}0.184 \\
(0.000)\end{array}$ & $\begin{array}{r}-0.392 \\
(0.000)\end{array}$ & $\begin{array}{r}-0.420 \\
(0.000)\end{array}$ & & $\begin{array}{r}0.511 \\
(0.000)\end{array}$ & $\begin{array}{r}0.295 \\
(0.000)\end{array}$ & $\begin{array}{r}0.000 \\
(1.000)\end{array}$ & $\begin{array}{r}0.633 \\
(0.000)\end{array}$ & 1.000 \\
\hline
\end{tabular}

The p-value is given in parentheses. 
Table 3 Regression models

\begin{tabular}{|c|c|c|c|c|c|c|c|c|c|c|}
\hline & (1) & (2) & (3) & (4) & (5) & (6) & (7) & $(8)$ & $(9)$ & $(10)$ \\
\hline Unemployment & $\begin{array}{c}-0.024^{* * *} \\
(0.006)\end{array}$ & $\begin{array}{c}-0.026^{\text {*** }} \\
(0.007)\end{array}$ & $\begin{array}{c}-0.014^{* * *} \\
(0.004)\end{array}$ & & & & & & $\begin{array}{l}-0.016^{* *} \\
(0.008)\end{array}$ & \\
\hline Unem_male & & & & $\begin{array}{c}-0.019^{* * * *} \\
(0.006)\end{array}$ & $\begin{array}{c}-0.028^{* * * *} \\
(0.007)\end{array}$ & $\begin{array}{c}-0.014^{* * * *} \\
(0.004)\end{array}$ & & & & \\
\hline Income $(\ln )$ & & & & & & & $\begin{array}{c}0.131 \\
(0.154) \\
\end{array}$ & $\begin{array}{l}1.165^{* * *} \\
(0.150)\end{array}$ & $\begin{array}{c}0.829^{* * *} \\
(0.195)\end{array}$ & $\begin{array}{c}0.622^{* * *} \\
(0.091)\end{array}$ \\
\hline Observations & 1817 & 1817 & 1817 & 1501 & 1501 & 1501 & 948 & 948 & 948 & 948 \\
\hline $\mathrm{R}^{2}$ & 0.099 & 0.145 & 0.123 & 0.063 & 0.194 & 0.148 & 0.004 & 0.387 & 0.412 & 0.335 \\
\hline District FE & NO & YES & YES & NO & YES & YES & NO & YES & YES & YES \\
\hline Year FE & NO & YES & YES & NO & YES & YES & NO & YES & YES & YES \\
\hline District $\mathrm{x}$ Year & NO & YES & YES & NO & YES & YES & NO & YES & YES & YES \\
\hline
\end{tabular}

Note: The dependent variable is the crude divorce rate. Robust standard errors clustered by district are given in parentheses. In model (3) (6) and (10) the logarithmic value of the dependent variable is used. All regressions are weighted by population of individual districts. Models with the variable Male unemployment rate have a lower number of observations due to data unavailability and map the period 2001 - 2019. Models with the included variable Income have fewer observations due to lack of data and take into account the period $2007-2019 .{ }^{* * *} \mathrm{p}<0.01 ;^{* *} \mathrm{p}$ $<0.05 ;{ }^{*} \mathrm{p}<0.1$ 
Table 4 Regression models taking into account legislative changes

\begin{tabular}{|c|c|c|c|c|c|c|}
\hline & (1) & (2) & (3) & (4) & $(5)$ & (6) \\
\hline Unemployment & $\begin{array}{c}-0.024^{* * *} \\
(0.007)\end{array}$ & & $\begin{array}{c}-0.027^{* * * *} \\
(0.008)\end{array}$ & & $\begin{array}{c}-0.025^{* * *} \\
(0.008)\end{array}$ & \\
\hline $\mathrm{EU}$ & $\begin{array}{c}0.505^{* * * *} \\
(0.035)\end{array}$ & $\begin{array}{c}0.320^{* * * *} \\
(0.044)\end{array}$ & & & $\begin{array}{c}0.519^{* * * *} \\
(0.030)\end{array}$ & $\begin{array}{c}0.320^{* * * *} \\
(0.046)\end{array}$ \\
\hline Unem_male & & $\begin{array}{c}-0.025^{* * * *} \\
(0.007)\end{array}$ & & $\begin{array}{c}-0.033^{* * * *} \\
(0.008)\end{array}$ & & $\begin{array}{c}-0.030^{* * * *} \\
(0.008)\end{array}$ \\
\hline Euro & & & $\begin{array}{c}0.007 \\
(0.065)\end{array}$ & $\begin{array}{c}0.361^{* * *} \\
(0.083)\end{array}$ & $\begin{array}{c}0.103^{*} \\
(0.062)\end{array}$ & $\begin{array}{c}0.361^{* * *} \\
(0.081)\end{array}$ \\
\hline Observations & 1817 & 1501 & 1817 & 1501 & 1817 & 1501 \\
\hline $\mathrm{R}^{2}$ & 0.203 & 0.219 & 0.145 & 0.218 & 0.204 & 0.243 \\
\hline District FE & YES & YES & YES & YES & YES & YES \\
\hline Year FE & YES & YES & YES & YES & YES & YES \\
\hline District x Year & YES & YES & YES & YES & YES & YES \\
\hline
\end{tabular}

Note: The dependent variable is the crude divorce rate. Robust standard errors clustered by district are given in parentheses. All regressions are weighted by population by individual districts. Models with the variable Male unemployment rate have a lower number of observations due to data unavailability and map the period $2001-2019$.

${ }^{* * *} \mathrm{p}<0.01 ;{ }^{* *} \mathrm{p}<0.05 ;{ }^{*} \mathrm{p}<0.1$ 
Table 5 Regression models with control variables

\begin{tabular}{|c|c|c|c|c|c|c|c|}
\hline & (1) & (2) & (3) & (4) & (5) & (6) & (7) \\
\hline \multirow[t]{2}{*}{ Unemployment } & -0.009 & $-0.012^{*}$ & 0.004 & $-0.019^{* * *}$ & 0.003 & & \\
\hline & $(0.007)$ & $(0.006)$ & $(0.005)$ & $(0.006)$ & $(0.005)$ & & \\
\hline \multirow[t]{2}{*}{ Median age } & $0.111^{* * *}$ & & $0.105^{* * *}$ & & $0.086^{* * *}$ & $0.104^{* * *}$ & $0.081^{* * *}$ \\
\hline & $(0.016)$ & & $(0.011)$ & & $(0.013)$ & $(0.011)$ & $(0.013)$ \\
\hline \multirow[t]{2}{*}{ Women } & & $0.101^{* * *}$ & $0.096^{* * *}$ & & $0.092^{* * *}$ & $0.081^{* * *}$ & $0.076^{* * *}$ \\
\hline & & $(0.018)$ & $(0.010)$ & & $(0.011)$ & $(0.010)$ & $(0.011)$ \\
\hline \multirow[t]{2}{*}{ Religious } & & & & $-0.554^{* * *}$ & $-0.196^{* *}$ & & $-0.248^{* * *}$ \\
\hline & & & & $(0.110)$ & $(0.076)$ & & $(0.074)$ \\
\hline \multirow[t]{2}{*}{ Unem_male } & & & & & & -0.000 & -0.001 \\
\hline & & & & & & $(0.005)$ & $(0.004)$ \\
\hline Observations & 1817 & 1817 & 1817 & 1817 & 1817 & 1501 & 1501 \\
\hline $\mathrm{R}^{2}$ & 0.329 & 0.374 & 0.536 & 0.293 & 0.549 & 0.527 & 0.549 \\
\hline District FE & YES & YES & YES & YES & YES & YES & YES \\
\hline Year FE & YES & YES & YES & YES & YES & YES & YES \\
\hline District $\mathrm{x}$ Year & YES & YES & YES & YES & YES & YES & YES \\
\hline
\end{tabular}

Note: The dependent variable is the crude divorce rate. Robust standard errors clustered by district are given in parentheses. All regressions are weighted by population by individual districts. Models with the variable Male unemployment rate have a lower number of observations due to data unavailability and map the period $2001-2019$.

${ }^{* * *} \mathrm{p}<0.01 ;{ }^{* *} \mathrm{p}<0.05 ;{ }^{*} \mathrm{p}<0.1$ 
Table 6: Regression models with lagged variables

\begin{tabular}{|c|c|c|c|c|}
\hline & (1) & (2) & (3) & (4) \\
\hline \multirow[t]{2}{*}{ Unemployment } & -0.002 & & & -0.006 \\
\hline & $(0.007)$ & & & $(0.008)$ \\
\hline \multirow[t]{2}{*}{ Unemployment (t-1) } & $-0.017^{* * *}$ & & & -0.001 \\
\hline & $(0.004)$ & & & $(0.008)$ \\
\hline \multirow[t]{2}{*}{ Unemployment (t-2) } & $-0.013^{* *}$ & & & $-0.012^{*}$ \\
\hline & $(0.005)$ & & & $(0.006)$ \\
\hline \multirow[t]{2}{*}{ Unemployment (Male) } & & 0.010 & & \\
\hline & & $(0.006)$ & & \\
\hline \multirow[t]{2}{*}{ Unemployment (Male) (t-1) } & & -0.001 & & \\
\hline & & $(0.005)$ & & \\
\hline \multirow[t]{2}{*}{ Unemployment (Male) (t-2) } & & $-0.039^{* * *}$ & & \\
\hline & & $(0.006)$ & & \\
\hline \multirow[t]{2}{*}{ Income (ln) } & & & $0.357^{* *}$ & 0.126 \\
\hline & & & $(0.171)$ & $(0.193)$ \\
\hline \multirow[t]{2}{*}{ Income $(\ln )(\mathrm{t}-1)$} & & & $0.285^{*}$ & 0.183 \\
\hline & & & $(0.171)$ & $(0.159)$ \\
\hline \multirow[t]{2}{*}{ Income $(\ln )(\mathrm{t}-2)$} & & & $0.453^{* * *}$ & $0.367^{* *}$ \\
\hline & & & $(0.135)$ & $(0.144)$ \\
\hline Observations & 1659 & 1343 & 790 & 790 \\
\hline $\mathrm{R}^{2}$ & 0.189 & 0.295 & 0.333 & 0.371 \\
\hline District FE & YES & YES & YES & YES \\
\hline Year FE & YES & YES & YES & YES \\
\hline District $\mathrm{x}$ Year & YES & YES & YES & YES \\
\hline
\end{tabular}

Note: The dependent variable is the crude divorce rate. Robust standard errors clustered by district are given in parentheses. All regressions are weighted by population by individual districts. Models with the variable Male unemployment rate have a lower number of observations due to data unavailability and map the period 2001 - 2019. Models with the included variable Income have fewer observations due to lack of data and take into account the period $2007-2019$.

${ }^{* * * *} \mathrm{p}<0.01 ;{ }^{* *} \mathrm{p}<0.05 ;{ }^{*} \mathrm{p}<0.1$ 


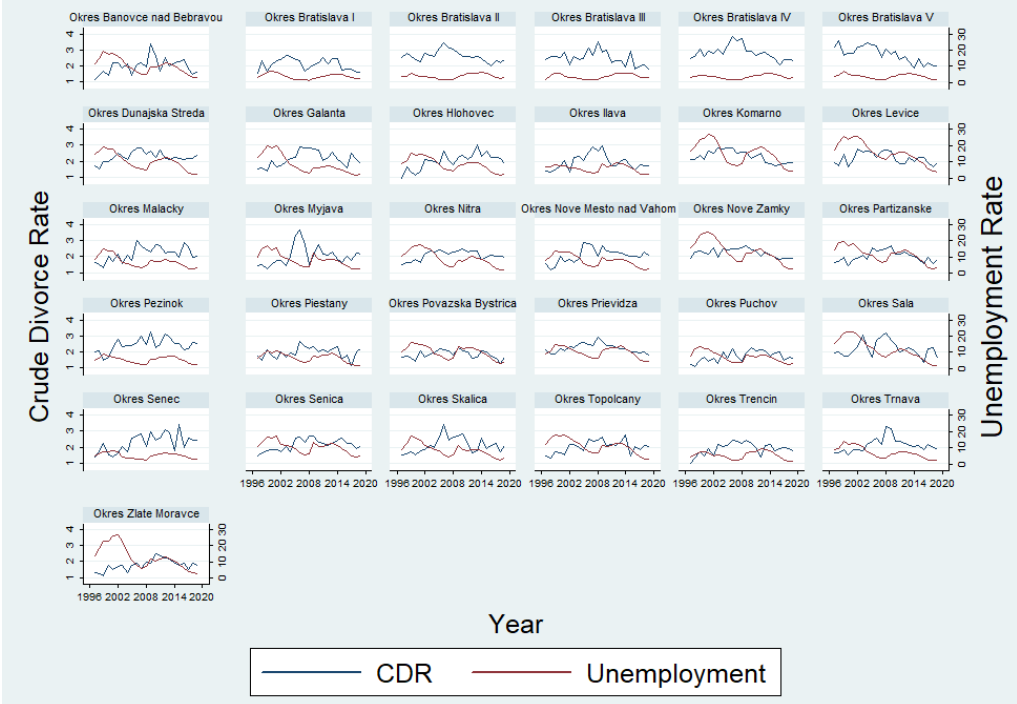

Figure 1 Crude divorce rate and unemployment rate by district

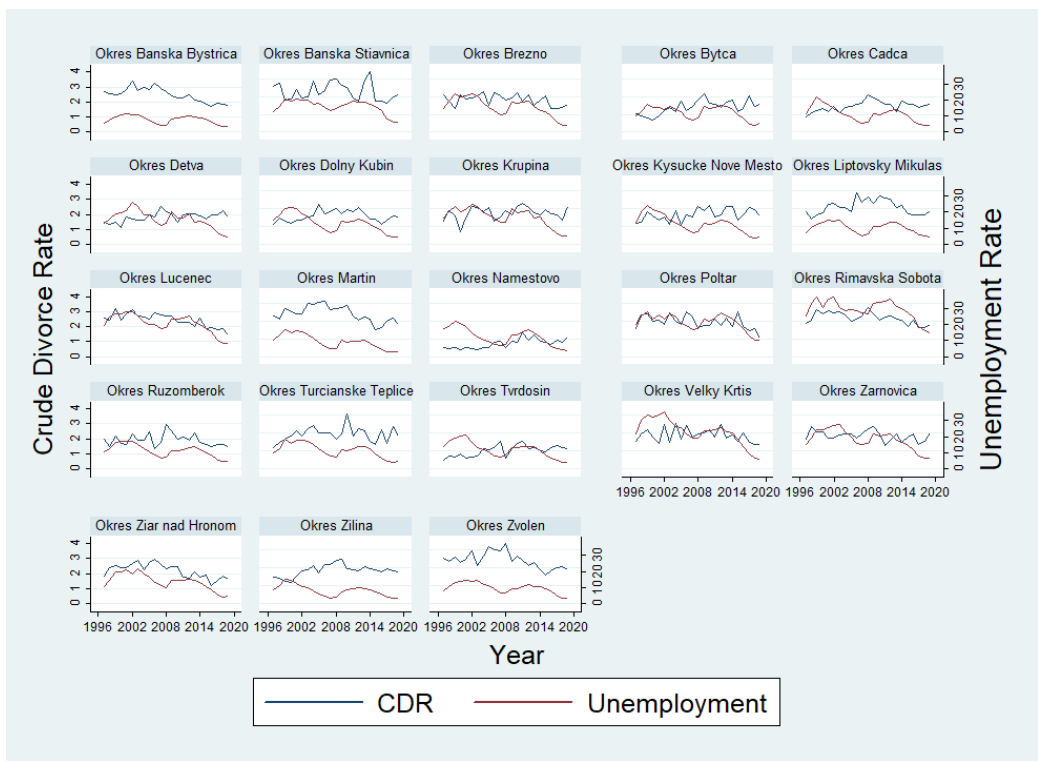

Figure 1 (continued) Crude divorce rate and unemployment rate by district 

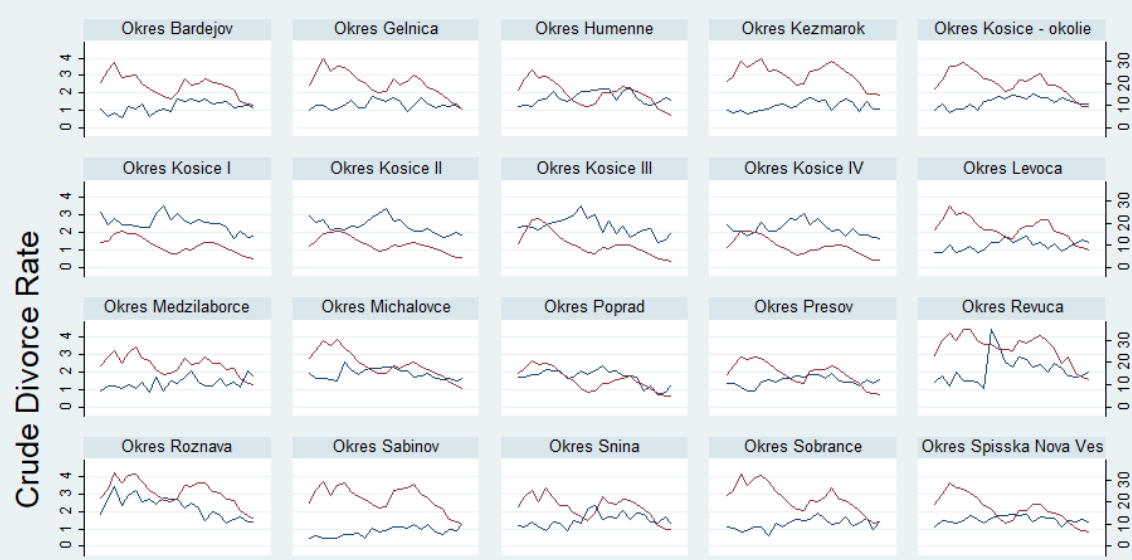

Okres Michalovce

Okres Poprad
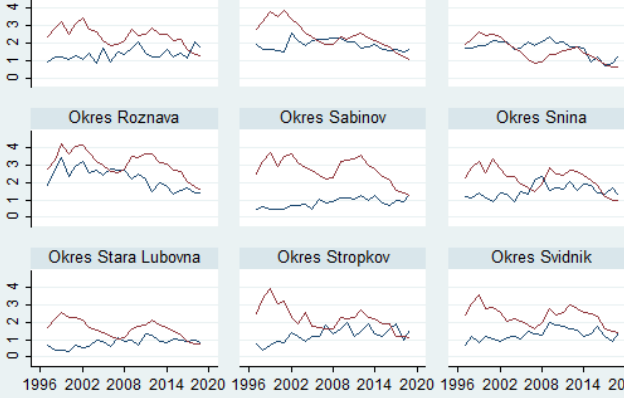

Okres Stropkov
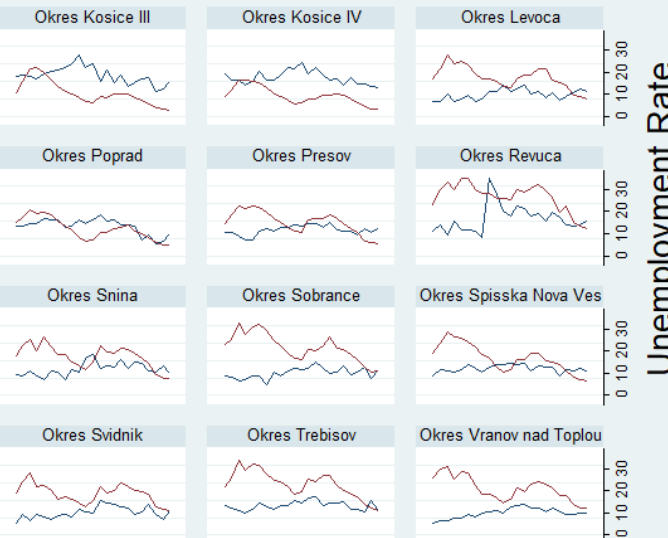

Okres Presov

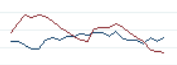

Okres Sobrance
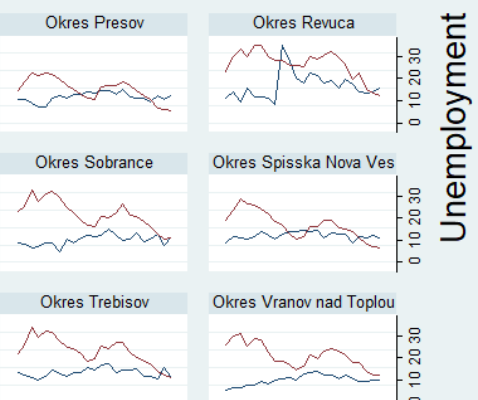

Okres Vranov nad Toplou

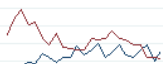

1996200220082014202019

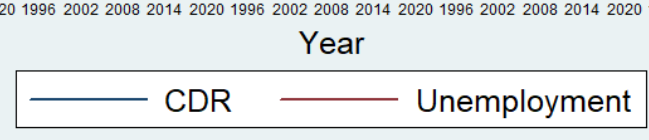

Figure 1 (continued) Crude divorce rate and unemployment rate by district

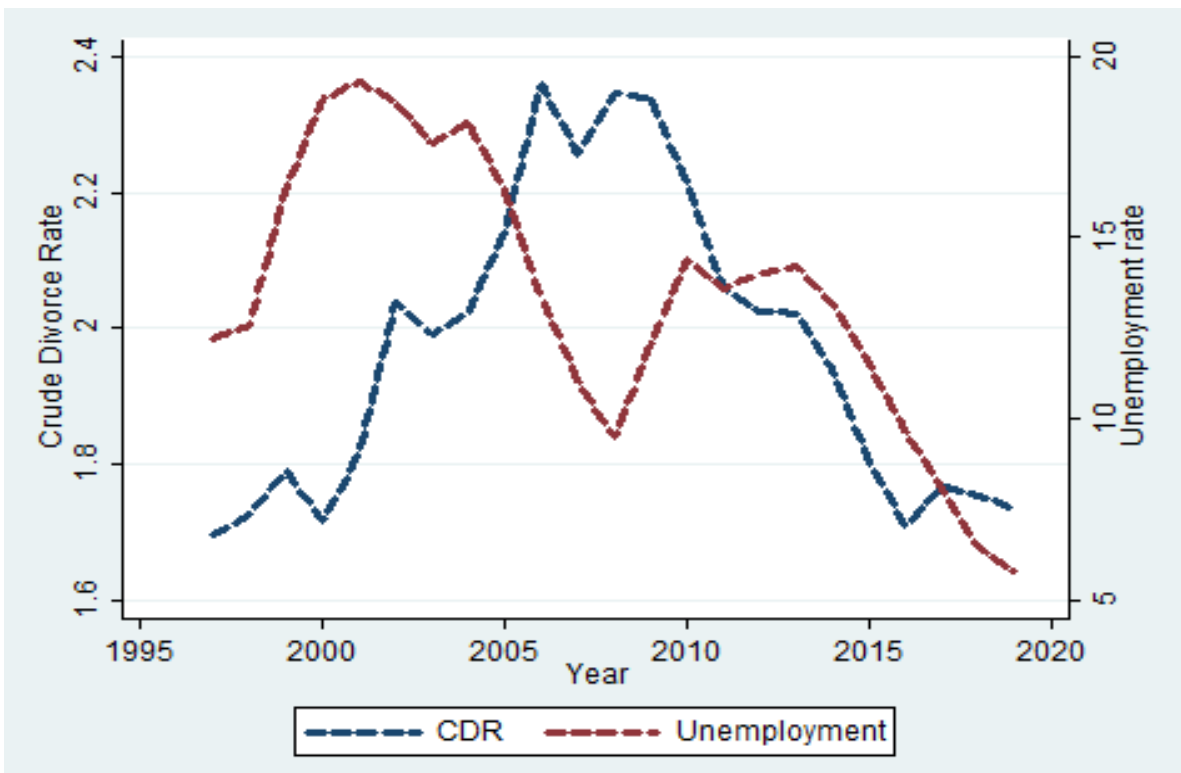

Figure 2 Crude divorce rate and unemployment rate in Slovak Republic 


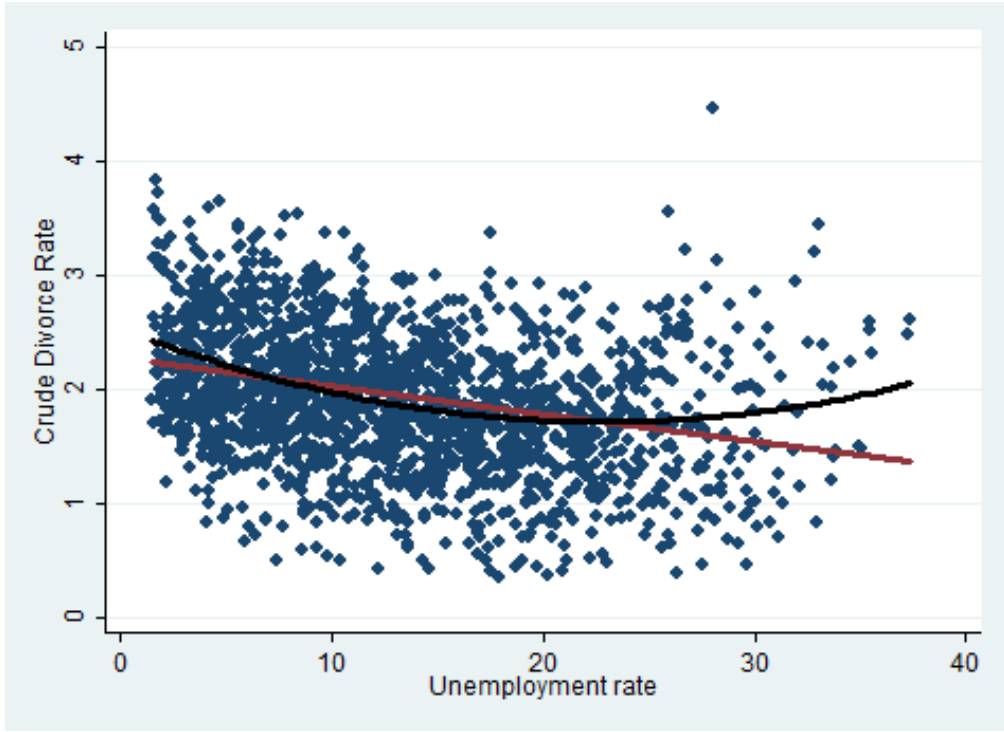

Figure 3 Scatterplot of the crude divorce rate and the unemployment rate

Note: The figure shows the data of both observed variables for the whole sample of 79 districts of the Slovak Republic and for the whole time period (1997 - 2019).

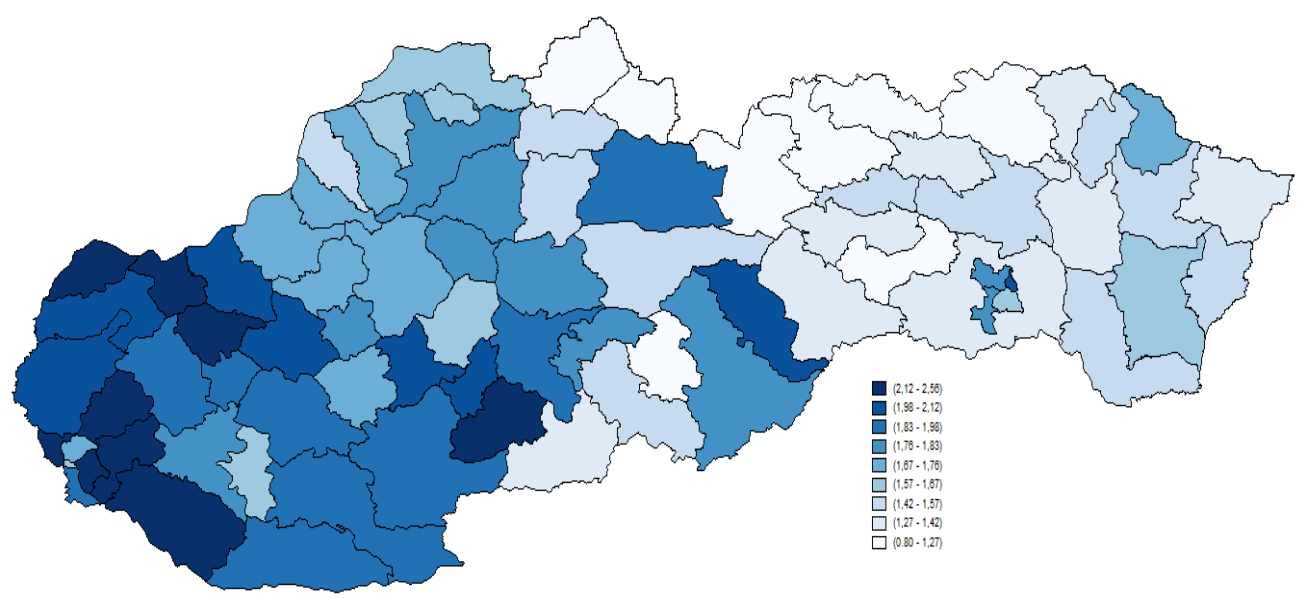

Cartogram 1 Crude divorce rate by district, 2019 


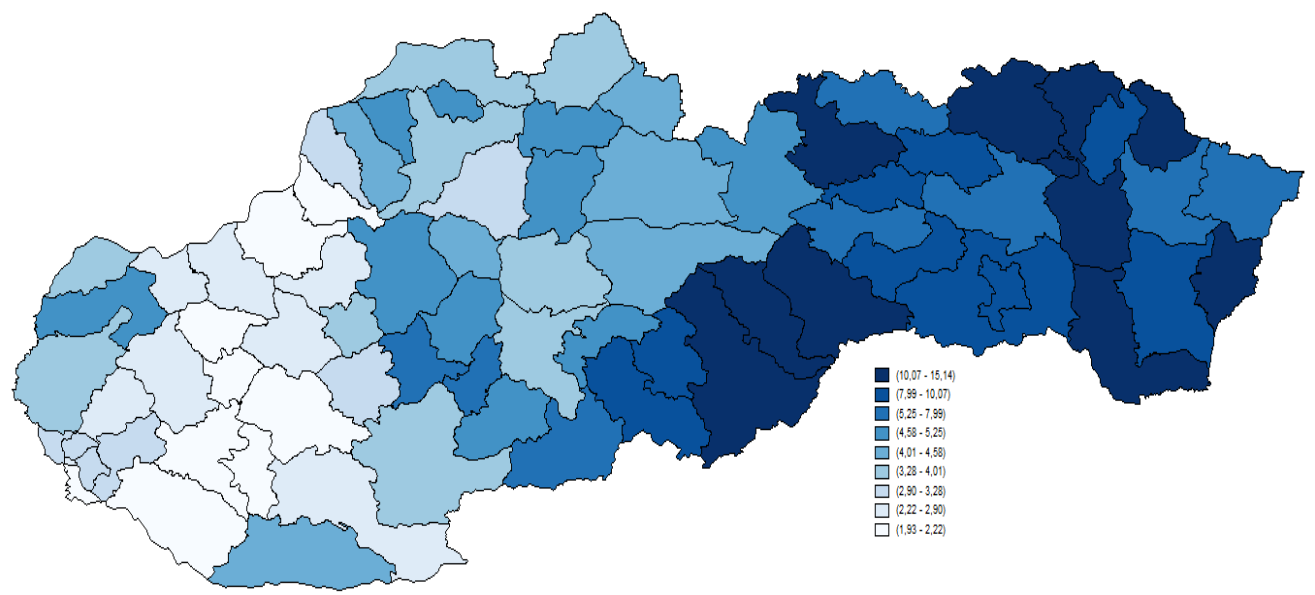

Cartogram 2 Unemployment rate by district, 2019

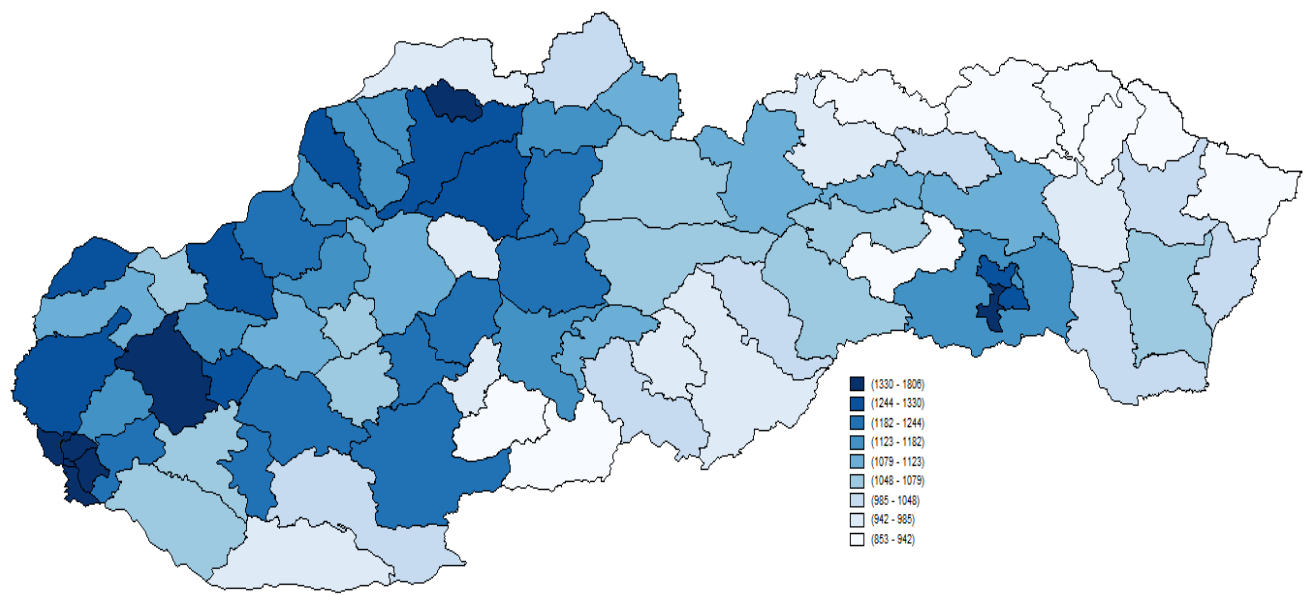

Cartogram 3 Average nominal monthly income by district, 2019 


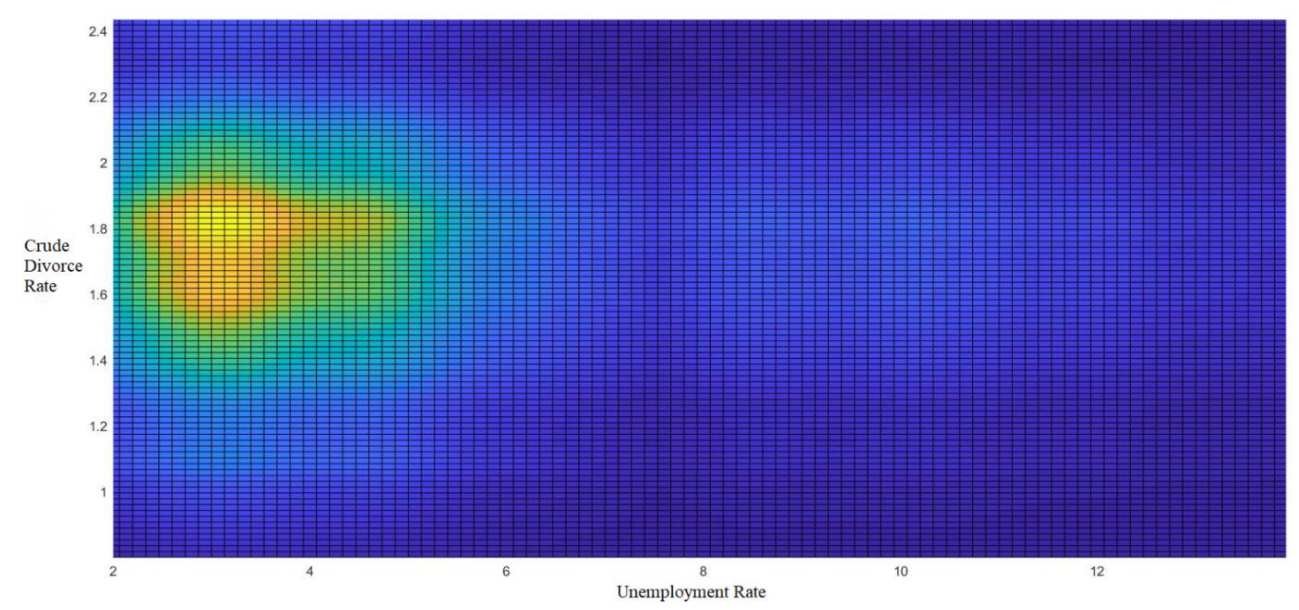

Figure 4 Kernel density analysis, 2D

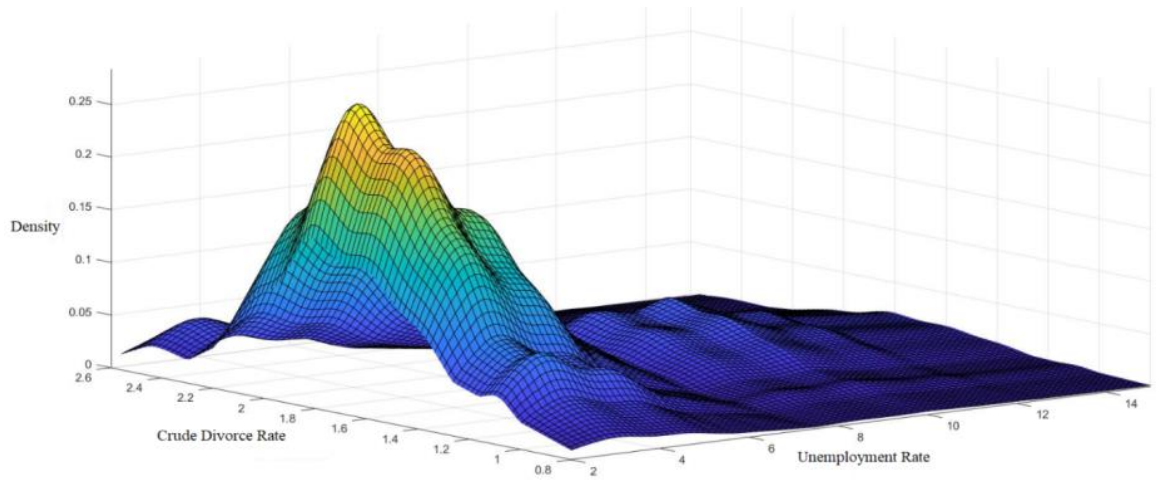

Figure 5 Kernel density analysis, 3D 


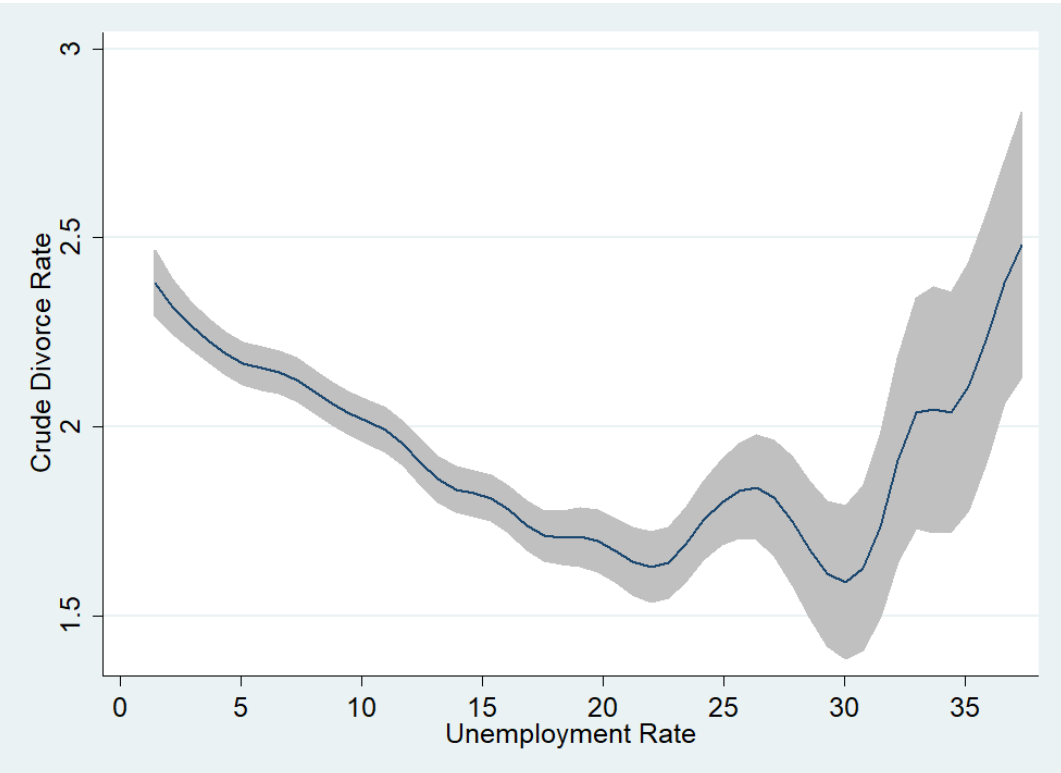

Figure 6 Nonparametric estimate of the relationship between the divorce rate and the unemployment rate

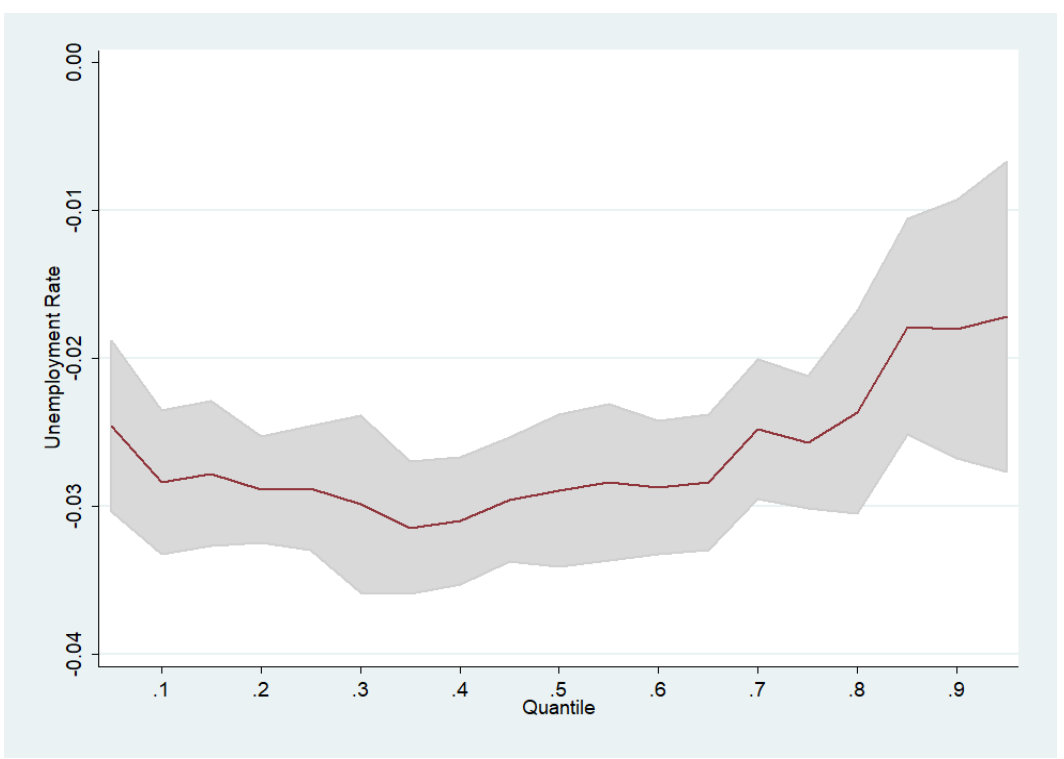

Figure 7 Quantile regression 